\title{
Urban Egalitarianism: The Way forward to Ensure Sustainable Urban Design, Practice and Development in Developing Countries (The Nigerian Case)
}

\author{
Ogunsola Segun Adeola \\ College of Art \& Design and Built Environment, Nottingham Trent University, United Kingdom
}

Copyright $(2016$ by authors, all rights reserved. Authors agree that this article remains permanently open access under the terms of the Creative Commons Attribution License 4.0 International License

\begin{abstract}
Cities and urban development across the world are entities with high complexity, most especially with the unavoidable ever increasing population which incorporates human diversity in culture, wealth and status. However, rapid urbanization and expansion is today a common phenomenon in many developing countries across the world, this is often characterized by challenges such as slum generation, informality, segregation and unequal distribution of infrastructure and resources among neighborhoods in the cities. Cities in developing nations have continued to grow in fragmentations, making their growth much more than the eyes can see, and the ears can hear and varieties of view-points wanting to be explored in great depth. In tackling this urban menace, sustainability and urban transformation through policies and strategies seem to be the major focus and agenda among urban development stakeholders globally. With this development, the environmental and economic spheres of sustainability have been granted higher priority over their social counterpart. However, the key question remains; "who and which group of people" benefit from these new urban spaces which have been proposed or created. Cities and urban spaces are meant to serve their citizenry irrespective of their class and status in the society, a situation where every individual is incorporated and engaged in the decision making and developmental process of the space in which they exist. In achieving this sustainable development and practice goals, this paper presents various integrated approach in which 'community and neighborhood' should be placed at the center of sustainability analysis and the discussion of spatial connectivity through urban design, development and practice with cases from Nigerian cities of Lagos and Abuja.
\end{abstract}

Keywords Sustainability, Urban Development, Segregation, Spatial Connectivity

\section{Introduction}

Discussions on the attainments of sustainable urban development and practice has continued to received global recognition, being a major focus among many academic and policy makers circle. The UN-Habitat report [35] attributes these developments to the inevitable ever increasing global urban population and its substantial variability in different regions across the world. Statistics from UN-Habitat [35] reviews that more than half of the world's population today is concentrated in urban centers across the globe and these has continued to experience a dramatic increase from $30 \%$ in 1950 to $54 \%$ in 2014 . This current statistics concerning the world's population growth and urbanization is also projected to increase by $66 \%$ by 2050 , with $82 \%$ increase in North America, 80\% in Latin America and the Caribbean, and 73\% in Europe. In addition, further changes are also expected to emerge with major concentration and fastest urbanization growth rate in developing nations across Africa with projections of $56 \%$ and Asia with $64 \%$ respectively by 2050 , making urbanization one of the most challenging issues facing humanity.

However, cities as an engine of urban development are noted for their complexity and related issues of size, perception, activities, culture and status, but remains homes to multitude of users which have continuously attracted various arguments and conflicts on what should constitute its development. For instance, urban development in African cities in recent years have responded not just to the effect of the continuous population explosion with its transformation and reproduction, but has also resulted in conflicts of interest and ideologies among social classes and built environment experts with the power to shape and produce urban planning and development between the three spheres of sustainability (social, economic and environmental). This brings Lefebvre's ideology of the production of space into consideration with its linkage with the built environment, geographical form, routine of life and symbolic meaning. In view of this, Lefebvre argues that space is produced and reproduced through human intentions, with consequences 
emerging, and should not be treated as a mere container or milieu.

In the context of Nigeria, Africa's most populated nation, majority of its cities with examples of Lagos, Abuja, Kano, and Port-Harcourt are currently undergoing some form of reproduction with modernization, renovation and industrialization which has prompted various arguments "for and against" these developments. The UN-Habitat [33] highlights the opportunities of urban growth as that which contribute to economic activities through employment opportunities, commerce and productivity, while serving as the hub that links rural areas and international boarders leading into the enormous migration of population. However, this report also significantly note that the reverse can also be the case with its negative impacts as that which threatens sustainable development such as the intense pressure on existing infrastructural development and public service of energy, water, sanitation, housing and health facilities. Olotua [23] provided elements of this negativity in the context of Nigeria's urban planning and development with examples of the rising inequalities and unequitable share of resources, the inability to manage urban expansion resulting in environmental impacts and sub-standard living conditions. Similarly, Adetayo [3] and Aribisala [4] have argued against this current urban development with its classification as a conformist agenda and imported urban ideological planning system in the aim of achieving sustainable urbanism in the Nigerian context. The examples of current developments such as the Eko Atlantic City in Lagos and the Abuja Centenary City were utilized as case-studies which have been criticized as projects which have created tension and conflicts among urban dwellers with little or no consideration into the existing urban realities. This development has been criticized as been tailor made to favor the capital class minority over the urban poor majority with the forced eviction and demolition of slum areas to pave way for appropriately planned contemporary neighborhoods with different occupants from the original owners or occupiers.

However, urban sustainability agenda on the global stage have continued to prepare cities for future development in accordance with the benchmark set by the World Commission on Environment and Development (The Brutland Report). This report WCED [39] emphasized the necessity to "meet the needs of the present generation without compromising the ability of future generation to meet their own needs". In addition, subsequent actions are underway such as the planned Third United Nations Conference on Human Settlement (Habitat III) for the year (2016). With this development, further discussions and reports are envisioned towards global urban sustainability with the aim of deriving new models for urban development and the promotion of equity, welfare, and shared prosperity in this fast rising urban world.

This is important in ensuring sustainable urban development as the recent transformation of cities in developing nations most importantly Nigeria have their national government focusing on economic indicators, the image of its cities, as well as the amount of foreign investors its urban development can attract with a limited attention on the final impact on the larger urban population, whose urban space are been developed without their inclusion and participation (Adetayo [3];Aribisala [4]; Olotua [23] ). Lynch [20] defined cities and their element both moving and stationary has been perceived differently by its dwellers, as such conveying an image, memory or meaning. In support of this position, this paper recognizes the impact of globalization as that platform which confronts urban challenges with the theme 'sustainability', but also emphasis 'egalitarianism' in the context of urban development and planning as a trend that is required by urban policy makers and stakeholders to actualize a sustainable urban development and practice in developing nations.

\section{Urban Transformation in Developing Nations}

In recent years, developing nations have experienced a major transformation in its urban developmental outlook, most importantly from the start of the new millennium year (2000). However, various sustainability reports such as UN-Habitat [35] and Dixon [10] has identified the important need to recognize and respond to these changes by providing new approaches to tackle any challenges synonymous to urbanization. According to demographic statistics from State of African Cities (2014), there are over 28 megacities with 453 million dwellers across the world with the fastest growing cities emerging in developing nations with a significant transformation in socio-political, demographical, economical, and technological terms. According to Campbell [8] and UN-Habitat [35], Tokyo is today the world's largest city with an agglomeration of 38 million inhabitants, followed by Delhi with 25 million, Shanghai and Mexico city with 23 million, Lagos, Mumbai and Sao Paulo, each with around 21 million inhabitants all in developing nations.

Nevertheless, for developing countries, these urban transitional periods have posed numerous urban social and environmental challenges for many of its dwellers, with many of this cities transforming into informal urban expansion, slum formation, urban disintegration and segregation with the neglect of the larger population becoming a common phenomenon. UN Habitat [33] presented the current state of urban form in many cities in developing nations as that which is developing in two separate 'contrasting' urban developmental patterns. One that is symbolized by poverty, informality, exclusion, and poor quality living environment with little or no infrastructure and services to support the well-being of its inhabitants, and the other with gated communities that is exclusive, formal with more than enough infrastructures and services.

This current urban menace provided a platform for many urban development and sustainability experts to debate on 
the future of urban planning in developing nations with an objective to meet the demands of the inhabitants and also protect the general environments of this transformed cities. In acknowledgement of this position, the UN-Habitat [33] report on the State of Cities in Developing Countries through an exploratory analysis of the current state and general environment in the cities of Shenyang and Wuhan in China, New Delhi in India, Port Harcourt and Lagos in Nigeria and Meuraxa in Indonesia all in developing countries as that which lacks the ability to tackle its current challenges characterized by the problems of management, exclusion, inequality, insecurity and environmental degradation; let alone provide solutions for future occurrence. UN-Habitat [36] also identified the non-existence of an adequate urban governance policy, participatory urban planning, and the lack of institutional capacity and the high rate of inequality among the different socio-economic population strata as the major factors which has deterred the attainment of sustainable urban development in many developing cities.

However, as earlier discussed, Aribisala's [4] argument concerning cities in developing nations most especially in Lagos, Nigeria's former capital are that with urban planning and operational process that is still largely based on the colonial laws in-terms of land tenure systems with regulatory decrees that are one-sided in developmental terms. Aribisala [4] and Adetayo [3] attributes this current trend on the enormous power vested on the state through planning laws and the sudden growth of the real estate market. Consequently, in the verge of attaining the status of world-class cities, Aribisala [4] further argues that the adopted modern urban culture and pattern from the developed nations are implemented without an understanding of the existing spatial formation of the cities and its compatibility with existing culture, traditions and the everyday life realities of the urban dwellers.

Nevertheless, writers such as Olesin [24] and Adetayo [2] have supported the new trend while presenting the position that urban planning and development in Nigeria needs to focus on the achieving smart modern city which synchronizes the demand of tomorrow's society with a sustainable ecological and socially responsible manner. Their argument also emphasis cities that serve as springboard and controlling liver for Nigeria's economy, an African epic center of global economic activity where modern beauty will merge with architectural creativity in creating an environment that is alive and productive. However, Harvey provides clarity into this situation with its position that space must be understood as an entity which exist, and its production analyzed epistemologically from the knowledge which emerges from the different activities and experience in such space. In support of Harvey's argument, this paper recognizes the production of Nigeria's urban centers as being that of domination versus appropriation to serve human needs; while asking the key question of how sustainable is the current urban planning practice, and if these current city development provides adequate solutions to the current urban challenge being faced.

\section{Sustainability and Urban Planning Process}

The concept and definition for sustainability have been presented from both implicit and explicit characterization by various references and reports. Writers such as Holland [15], Dillards et al [9] and Pole'se \& Stren [24] presents an implicit characterization of sustainable urban planning from the perspective of showing higher priority or concern for a particular or some aspect of sustainability over the other. Lombardi [21] further identifies an explicit view-point with the derivation of an appropriate solution from a broader perspective of enumerating all aspects of sustainability that is vital. However, international forums on sustainability agenda such as WCED [39], LCSEC [22] and UNCSD [29] have continued to present a holistic structure to harmonize the diverse interest towards sustainable planning and design for cities. This as an integrated approach which unifies all interest in urban developmental procedures with the need to ensure an inclusive and participatory process that involves all stakeholders in the determination of the built environment and also the livelihood of its inhabitants from a long-term approach.

Planning procedures plays a vital role in urban development designs and formation through an outlined analysis and evaluation of all current and eventuated challenges on the basis of real world case studies and planning examples. In support of this argument, the global report on Human Settlement (2009) identified series of factors which impacts on the current state of the sustainable urban and living conditions of many city dwellers across the world. This include demographic challenge in the case of rapid urbanization as previously stated, democratization opportunities through the awareness of social and economic rights, economic challenge and its connection with the uncertainty of future economic growth, and social and spatial inequality resulting in urban sprawl and informal urbanization. In reference to this challenges, urban planning fundamentals urge to be reinvented by concerned stakeholders whereby the new imperatives and demand on policies and strategies are derived with an appropriate solution through contextualized information, communication tools, with an inclusive modelling method been finalized by design and implementation. Urban planning and practice of 21 st century cities must also transform these key challenges into opportunities by creating cities that work for all its citizenry in- respective of their status by:

\section{Tackling Informality Instead of Contrasting It}

The form of any city is largely determined by its urban development and practice; this is evident with the current state of transformation been experienced in many cities across developing nations. According to UN-Habitat [36] cities such as Lagos, Abuja and Nairobi among many others have urban practices and developments characterized by contrasting neighborhood settings. The wide gap between 
various class and social strata in the society remains a major factor that influences urban divide, exclusion, and contrasting neighborhood settings in many of these cities. However, UN- Habitat [36] identified the enforcement of negative regulatory laws as a control mechanism been utilized to tackle urban informality at all cost in cities in developing countries, which was also argued to be a major factor leading into acquisition and sub-division. Many urban dwellers in these regions of the world are subjected to high level of rejection and neglect, as the level of inequality has continued to rise without much concern and attention from policy makers and city developers with supportive strategies in the provision of an inclusive city for all.

In achieving an inclusive urban space, effective urban planning developmental practice can be utilized as a tool to achieve the much anticipated inclusion as well as reverse the trend of informality and the growth in slum development. However it is significant to note that the transformation for better outcomes does not happen automatically, as appropriate policies that support the needs and living conditions of the urban poor must be implemented with emphasis on the importance of every individual and their community. This creates a balance between urban growth and sustainability with key elements such as the restructuring of institutions, equity in resource allocation, leadership re-development and political vision and value as well as effective implementation and monitoring.

UN-Habitat [36] identified the strategic use of planning tools through improved urban governance as a critical element in tackling contrasting neighborhoods. It is also considered as the foundation for urban planning approach that is switched from a 'command and control' model to that which incorporates an inclusive and participatory process. This can become a reality by first providing a strategic plan for the equal provision of infrastructure guided by land development or land re-adjustment as a possible solution to an upgrade for informal settlements. Urban planning process must be participatory through meaningful and collective engagement with the involvement of the general public in all the decision making process, implementation and monitoring. Secondly, the collaboration between private and public sector, community based groups, and international development partners must also be encouraged as an avenue which can strengthen the legitimacy of planning and regulatory system with the aim of achieving progress through adequate standards and regulations. Thirdly, legislative and policy framework through institutional processes are vital procedures in achieving sustainable cities and spatial planning. This facilitate the intersectional coordination and position urban planning at the intersection of public policy and resource allocation For instance, in the case of cities such as Kusumu, Kenya's third largest city as discussed by UN-Habitat [35], where data gathering process and surveys provided planners with an up-date information concerning the needs of the residents with the utilization of a city-wide Geographic Infrastructure System to ensure the effective planning for their slums. Through this, urban planning becomes tools for local democracy and inclusive governance which responds to the needs of the city dwellers rather than regulates it. Furthermore, participatory planning empowers communities with an outcome of a better spatial design that is responsive to the needs of different urban groups which obviously impacts on the quality of life.

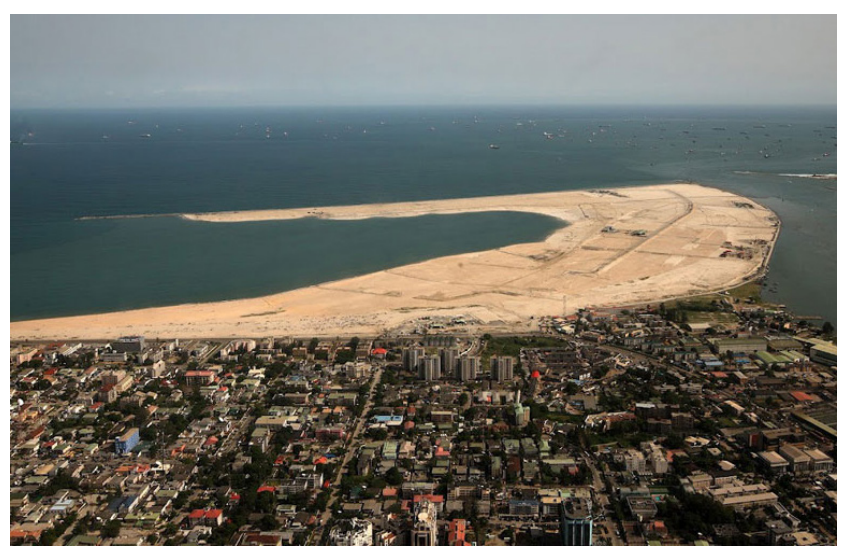

Source: Eko Atlantic http://www.ekoatlantic.com/media/image-gallery/

Figure 1. Land reclamation for the Eko Atlantic Project Lagos, Nigeria.

In view of the above, Lynch [20] also argued that not only is the city an object to be perceived, but remains a product of many builders that is constantly modified to suit their purpose. As such, the sustainability of any city depends on its capacity and the livability of all city dwellers through an efficient urban infrastructure and built environment. In recognition of these positions, urban planning and practice have been recognized by the World Urban Campaign [28] as the instrument which determines the sustainability of any city by the promotion of a participatory engagement, strategic thinking, vision building and territorial coordination which must be clearly understood in the context of the area been examined. Reports from the Second and Third World Urban Forum in Barcelona and Vancouver $(2004,2006)$ reinvented the functions of urban planning and practice with wide acceptance and a consensus from planning experts and stakeholders with the establishment of the 10 principles:

- The promotion of sustainable development

- Achieving integrated planning

- Integrate planning with budget

- Planning with partners and stakeholders

- Meeting the subsidiary principles

- Ensuring accessibility to land promoting

- Market responsiveness

- Developing appropriate planning tools

- Be pro-poor and inclusive

- Recognition of cultural diversity.

Researchers and built environments experts during this forum emphasized the need to continuously update urban planning process and policies of cities, as they remain the key instruments to bridge the gap between the two urban groups of the rich and the poor as well as achieving inclusive, participatory and culturally meaningful cities. This paper 
argues in support of this position as an appropriate solution to the current urban challenge identified by Aribisala [4], Bean [6] and Beski [7] in Nigerian cities with the creation of modern development which focuses on value exchange and is majorly for abstract representation. This development has supported spatial segregation, population control and is limited to beautification and decoration of the urban space while the majority of the urban population is evicted without a relocation or compensation plan.

\section{Urban Development and the Quality of Life for All}

The term 'quality of life' for city dwellers across the world has often been discussed, debated with various interpretations and meaning in response to urban developmental challenges. In the desire to interpret the urban quality of life concept in a particular place, person or group, many research and report such as UN-Habitat [33] have based their ideology of the quality of life on human satisfaction with different elements of cost and living conditions with access to basic goods, service, infrastructure and public amenities. Also identified by Haman Serag et al [14] are the equity and respect for diversity and cultural identities, and land use pattern within local level with an objective of meeting the diversity of needs and expectation of the citizenry. According to Nobel Laureate Amartya Sen with its report in UN-Habitat [33], the quality of life of an individual is determined by various opportunities open to such person and their freedom to choose from these many opportunities. As such, Haman Serag et al [14] further presented the view point that urban quality of life is a multi-dimensional concept which is analyzed in accordance to place and societies. Using this perspective, he also argued that the urban quality of life cannot be understood from one view point, but that which incorporates over dimensions that are inter-related and dependent on each other. Seven main dimensions were identified as that which contributes to the realization of any urban quality of life, these are:

- The physical: This takes into account the sustainability of the urban fabric, through planning, provision and management of the city layout, services and infrastructure.

- The social: The promotion of social justice, equity and interaction for urban dwellers to interact with the access to the freedom of choice while participating actively in their respective communities.

- Psychological: The creation of an urban environment that recognize opinions of every citizen in-terms of identity and sense of place.

- Economic : The creation of an urban space as a place for activities that support human development through job creation and the promotion of local business opportunities while encouraging mixed use development.
- Political: The democratization of urban policies that promotes integration with the involvement of every stakeholder in the community in decision making.

- Mobility: This focus on accessibility and transportation issues with the provision of a network interconnecting streets through friendly pedestrian and cycle pathway to reduce traffic load, minimize air pollution and also encourage walking.

- Environment: The provision of natural landscaped natural green area distributed equally within every neighborhood in an urban area.

In addition, Haman Serag et al [16] argument on sustainable urban development identified the improvement of the quality of life of every citizenry as vital in any sustainability agenda with the emergence of new urban planning theories such as new urbanism, smart growth, urban village and intelligent urbanism. These urban theories further promoted the urban quality of life concept with the consideration of the seven identified dimensions in the design of buildings, neighborhoods and cities that focus on the sense of community and place, along with people's needs and well-being.

In recent times, efforts have also shifted from the definition to the measurement of quality of life with a presumed argument that individuals are the best judges of their life conditions by providing relevant information about a crucial component of social change through values, beliefs, and the motivation of the ordinary citizen.

However, quality of life underpins the functionality of any city which its notion is at the crossroad of all policies and actions. For instance, human development capacity and economic growth of a city is enhanced by means of empowerment of its citizens through the equal and accessible opportunities been provided. Also the improvement of the quality of life and living condition for every urban dweller is largely based on the urban planning and design process which is vital in the provision of adequate infrastructure and services of public transport, housing, public space, and drainage system to support the well-being of every citizenry. The UN-Habitat Survey [32] also identifies security, human right, and housing with basic facilities as well as employment with a decent salary as the most important factors which support urban quality of life. In view of these positions, it is obvious that the quality of life of every group in an urban development is an essential element in the determination of how sustainable a city can be, which has made the fulfillment of needs and well-being a burning issue globally.

\section{Urban Politicking in Nigerian Cities}

Urbanization rate in Nigerian cities is one of the highest in the world couple with the demographic fact of being the most populous black nation on earth, with an urban development pattern that takes the form of a central core with peripheral 
area that are suburban with peri-urbanization. According to Dobbs [11] the recent economic growth in Nigeria with its emergence as Africa's largest economy in 2014 is marked with trends of imported developmental models of revitalization, renewal and redevelopment in its urban growth.

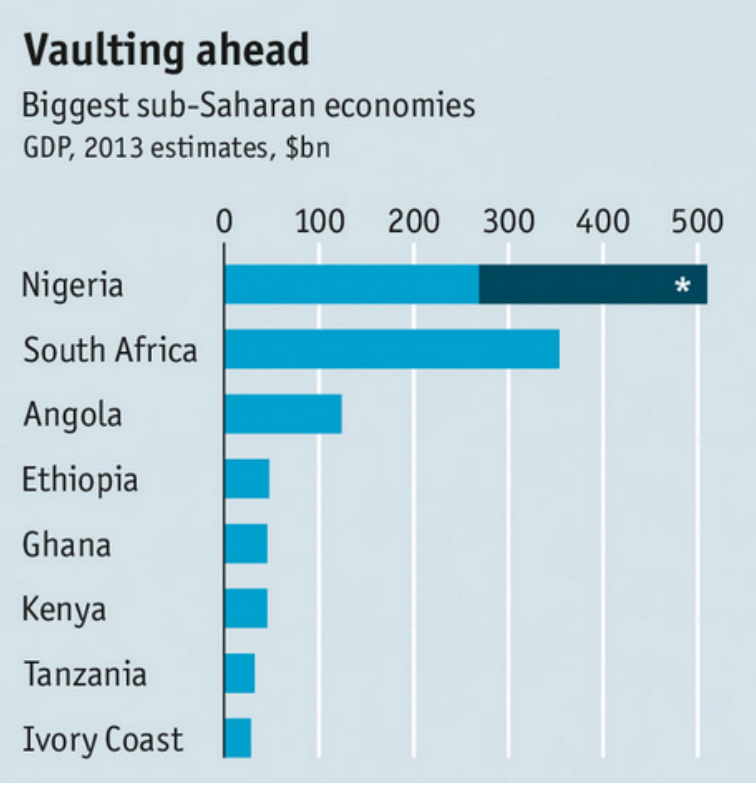

Source: The Economist:

http:/www.economist.com/news/finance-and-economics/21600734-re vised-figures-show-nigeria-africas-largest-economy-step-change

Figure 2. IMF National Statistic on Biggest Sub-Saharan Economics

Urban development researchers such as Adebayo [2] and Bean [5] have argued that these initiatives has recorded both successes and failures from various quarters of the society, one with creative and ambitious development that focus on certain class of groups in the society with a strong political and economic tool to secure foreign investment, promote international attention and indeed signaling a new economic awakening and pride for the country. While the other is the promotion of urban development away from the major population concentration, with a disconnection driven by negative policies and control system leading into subdivision, segregation, forced eviction and social inequity. Aribisala [4] also explained further that the community power structure of Nigerian cities is that which the business and elicit group determine and regulate all the major urban planning decisions on behalf of millions of other city inhabitants.

However, this paper identifies the need to distinguish between the pursuits of spatial use versus exchange values. This with urban policies that are people oriented as against the current urban development practice in Nigerian cities. Discussions from the (2012) United Nations Conference on Sustainable Development established the need of achieving an equilibrium in global urban development with an integrated equitable delivery and access to land, housing, basic services and infrastructures. In creating such equilibrium in the context of Nigeria's urban development and practice, it is important to first examine the objectives of the current urban policies and development with the key question of 'to whose advantage and benefits' are the current developmental policies and plan. As such, there exists a complex sociological problem of trying to strike equilibrium between the power groups in the society and among other groups. According to Branne [6], in an attempt to operate a planning machinery in a society with a kind of balancing scale between the state and the individual, the major challenge remains how to maintain an 'equilibrium' in which all goals through its planning process must be geared towards. For instance in the case of Lagos, West African commercial hub and Africa's largest city with United Nations [35] estimated population of 21 million residents, Olesin [24] argues that the planning and regulatory efforts of the city authority have been routinely thwarted by economic and political intervention. Hence, suggesting a capitalist undertone leading to a highly unequal urban divide segregated by class and social strata. A typical case is the example of the forced eviction and destruction of urban slum and informal settlements such as Makoko and Badia, both slum communities on the edge of Lagos. Reports such as Bean [5] have argued that the eviction exercise was not aimed at achieving sustainable development for Lagos, but was undertaken as a result of the increase in land value and its proximity to highbrow neighborhoods areas of Victoria Island, Ikoyi and Lekki, while paving way for planned communities with adequate infrastructures far beyond the reach of the initial occupiers and settlers.

Urban development condition in Nigerian cities explains Lefebvre's spatial Capitalism concept where capital now actively shapes urban spaces either as pre-existing or producing new ones. This paper argues that urban spaces in the city of Lagos and Abuja are not just revitalized or produced to achieve ideological results, but are more focused on their lucrativeness and market value.

\section{The Makoko Saga}

Makoko, a fishing community which consist of dozens of stilt structures built over Lagos lagoon is habituated by very poor urban dwellers struggling to contain a rapidly expanding population. According to Bean [5] this slum settlement provides its residents with shelter to live and work with the lagoon serving as the main source of livelihood from the sale of fish to the rest of the city of Lagos. However, the government of Lagos has unfortunately identified the growth of this neighborhood as illegal and dangerous, as the unhealthy environment continuously expands causing water contamination and flooding as a result of the lack of sanitation and waste management. 


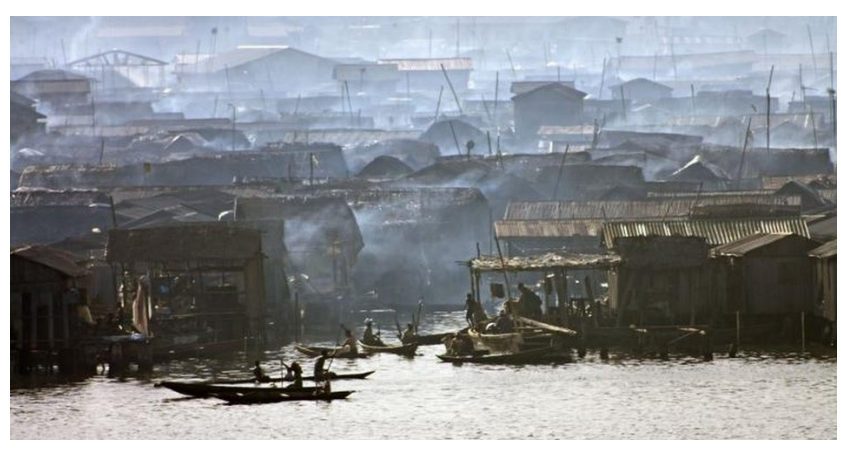

Source: BBC News: http://www.bbc.co.uk/news/world-africa-18872929

Figure 3. Makoko Lagos Lagoon Slum Development

However, Beski [6] provides a detail account on how the Lagos city urban development administration commenced the demolition of Makoko following a 72 hours advance notice of eviction with more than 30,000 residents evicted and displaced into a worse living condition with no assistance for relocation. Argument in support of the slum clearing action by the government was presented as effort to clean up Lagos, and ensure environmental sustainability as the unwholesome structures constitute an environmental nuisance, security risk, an impediment to the economic and gainful utilization of the waterfront. In addition, reports such as Adeoye [1], Fortin [12] and Beski [6] also identified Makoko as a slum that is easily visible from the Third Mainland Bridge which connects Lagos mainland to the city's rich and business districts, and its scenery does not represent Lagos as a true emerging world class city in positive light. The case of Makoko substantiates Lefebvre's spatial Marxism, where capitalism reaches globally, so deep into the earth while creating conflict of interest between economic advancement and the everyday life realities on the other. Lefebvre argues that an "authentic knowledge of space is required in the question of its production", this as a major support of the critique of the Nigerian urban space; most importantly as globalization as taken the center stage over local action. The original residents of Makoko are today subjected to forced eviction, demolition and neglect, as the big price for the modernization of the city of Lagos.

\section{The Abuja Land Swap Concept (Kuruduma)}

Nigeria's capital city of Abuja is today facing the challenges of rapid urbanization, most importantly with the provision of adequate public infrastructure and housing to meet the demand of its growing population. The city's urban development authority initiated the 'land swap concept' a new policy with an objective to ensure comprehensive development of districts in line with the Abuja Master-plan and also generate secondary investment. According to Ibezim-Ohaeri [17], this concept awards large hectares of Greenfield lands to competent private developers in exchange for the provision of public infrastructure and modern housing. In recent years, farm lands and indigenous houses within the territory of Abuja earmarked for the land swap concept are been marked for demolition and are gradually paving way for contemporary development. Arguments presented in support of this policy by the Abuja City Development Authority are based on the fact that the land swap initiative presents an incentivized solution to the persisting urban challenge characterized by pressure on existing infrastructure and the lack of funds by the government with the primary objective of fast-tracking housing and infrastructural development. Ibezim-Ohaeri [17] recognizes the fact that the contractual relationship between the Federal Capital Development Authority (FCDA) and private developers does not outline community roles and benefits under the project, therefore making the continued existence of the original settlers and owners of the land in the transformed neighborhoods a dream that may never come through. The aggrieved indigenous communities in the concerned satellite towns and villages such as the case of Kuruduma who are ancestral owners of the land have protested against the implementation of this public-private-partnership model as lacking an inclusive participatory process in its formation and implementation. The residents of Kuruduma are been evicted forcefully away from their inherited homes and cultural space with adequate compensation and inclusion into the new development.

However, this paper supports the 'right to the city' of every urban dweller in the case of the city of Abuja. This based on Lefebvre analyses which distinguish a valued absolute space, from a devalued abstract one. Lefebvre's argument presents the viewpoint that a person of haut sensibilities knows what he likes and fails to notice the exploitation which made possible lovely edifice. In view of this position, the understanding and perception of space or an environment is best derived from the expression of the phenomena of its users, making such a space an integral part of their existence. Therefore, it is important that the urban planning process in the city of Abuja recognize the social realities, cultural values and ethnic affinities which shape the everyday lives of the residents of Kuruduma as a mechanism to shape the urban space in which they occupy, rather than replace them with contemporary neighborhood patterns.

\section{Conclusions}

The connection between an urban space and its occupants cannot be overemphasized as 'equality and justice' is required in Nigeria's urban development as an all-inclusive framework where communal engagement and collaboration occurs in creating sustainable urban development, rather than solving a challenge with the emergence of another. These can also be attributed to the inability of the government to plan and engage in an envisioned process with consideration of human progress and needs from a long-term perspective for all interest groups within the society. An effective urban planning system standard ensures the formulation, implementation and proper monitoring of 
policies and strategies. These allows the creation of places where people can live, work and interact with special consideration on community safety, sense of place, social cohesion, equity and justice, interaction between urban form, nature and the built fabric in achieving a more successful and sustainable city. Furthermore, urban planning and practice in developing countries must ensure that the development of cities encompasses much more than just a concrete space in accordance with the Lefebvre's spatial triad, but a perceived (everyday life and environment), conceived (mental construction) and lived space (combination of perceived and conceived). The spatial triad presents the production of an urban space beyond just planning and the material space of the city; but the production and reproduction in recognition of all aspect of urban life which includes the every individual in respect of their class and status in the society.

\section{REFERENCES}

[1] Allen A. (2009). Sustainable Cities or Sustainable Urbanization. Taken from the Summer 2009 edition of UCL's Journal of Sustainable Cities. www.ucl.ac.uk/sustainable-citi es.

[2] Adeoye G. (2012). Lagos State Government Defends Makoko Demolition. July $19^{\text {th }} 2012$ Daily Times Nigeria. http://www.dailytimes.com.ng/article/lagos-state-governmen t-defends-Makoko-demolition. Accessed August $27^{\text {th }} 2014$.

[3] Adetayo O. (2014). Abuja's N3trn Ambitious City within the City. The Punch Newspaper. July 10, 2014.http://www.punc hng.com/feature/nations-capital/abujas-n3trn-ambitious-citywithin-the-city/. Accessed August $27^{\text {th }} 2014$.

[4] Aribisala F. (2013). Warning: Poor People Are Not Wanted in Lagos Mega-City. The Vanguard Newspaper. September 17, 2013.http://www.vanguardngr.com/2013/09/warning-poor-p eople-are-not-wanted-in-lagos-megacity/. Accessed $5^{\text {th }}$ Sept ember 2014.

[5] Branne R. (1956). Towards a Theory of Urban Planning Standards. Massachusetts Institute of Technology. Department of City and Regional Planning.

[6] Bean A. (2011). Protest Continue after Demolition of Coastal Slum in Lagos. July $25^{\text {th }} 2011$. IHC http://intlhc.org/blog/pr otests-continue-after-demolition-of-coastal-slum-in-lagos. Accessed $5^{\text {th }}$ September 2014.

[7] Beski D. (2012). Lagos Makoko Slums Knocked Down in Nigeria. BBC World News. http://www.bbc.co.uk/news/world-africa-18870511. Accessed $5^{\text {th }}$ September 2014.

[8] Campbell J. (2012). This is Africa's New Biggest City: Lagos, Nigeria Population of 21 Million. The New York Times. July 12,2012

[9] Dillard J., Dujon V., King C., 2009.Understanding the Social Dimension of Sustainability. New York: Routledge.

[10] Dixon T. (2011). Sustainable Urban Development to 2050: Complex Transition in the Built Environment of Cities. Oxford Institute for Sustainable Development, Oxford
Brooks University.

[11] Dobbs R. Fiorini R. Leke A. Suleiman A. Thompson F. Wright D. (2014). Nigeria Renewal: Delivering Inclusive Growth in Africa's Largest Economy. McKinsey Global Institute. May 2014.

[12] Fortin J. (2012). The 'Poor Man's Venice': Nigeria Demolishes Makoko in Lagos, Evicting Thousands. International Business Times. http://www.ibtimes.com/poormans-venice-nigeria-demolishes-makoko-lagos-evicting-tho usands-723329 July $17^{\text {th }} 2012$. Accessed August $24^{\text {th }} 2014$.

[13] GPHCDA (2014). Greater Port-Harcourt City Development Authority. http://www.gphcity.com/. Accessed August $29^{\text {th }}$ 2014.

[14] Harvey D. (1993). Social Justice and the City. Oxford: Blackwell Publisher.

[15] Holland A. (1995). The Use and Abuse of Ecological Concepts in Environmental Ethics, Biodiversity and Conservation, vol.4, pp.812-826.

[16] Hamam S. Ahmed S. Elsayed F. Sarah A. (2013). Principle of Urban Quality of Life for a Neighborhood. Housing and Building National Research Centre Journal 2013 Volume (9) $86-92$

[17] Ibezim-Ohaeri V. (2013). Spaces for Change, Abuja Land Swap Initiative: The Challenges Within. Policing the policy Series / Volume 9. May 2013.

[18] Lefebvre H., (1991). The Production of Space. Oxford: Blackwell.

[19] Lefebvre H., (1996). Writings on Cities. Cambridge: Blackwell.

[20] Lynch K. (1960). The Image of the City. Massachusetts Institute of Technology. MIT Press. Lombardi P.L. and Brandon P.S., (1997) Toward a Multimodal Framework for Evaluating the Built Environment Quality in Sustainability Planning, in Brandon et al. (eds.), Evaluation in the Built Environment for Sustainability, E\&FN SPUN, Chapman \& Hall, London, pp.6-21.

[21] Lombardi P.L. (1999). Understanding Sustainability in the Built Environment. A Framework for Evaluation in Urban Planning and Design. Department of Surveying, University of Salford, U.K

[22] LCSEC (2007). Leipzig Charter on Sustainable Europe Cities. $2^{\text {nd }}$ May 2007. http://ec.europa.eu/regional policy/archive/t hemes/urban/leipzig charter.pdf Accessed August 24 2014.

[23] Olotuah A. (2010). Housing Development and Environmental Degeneration in Nigeria. Department of Architecture, Federal University of Technology, Akure, Nigeria. The Built Environment Review. Volume 3, 2010

[24] Olesin A. (2013). Eko Atlantic City as Benchmark for Urban Renewal. National Mirror Newspaper. February 25, 2013.

[25] Pole'se M., Stren R., 2000. The Social Sustainability of Cities: Diversity and the Management of Change. Canada: University of Toronto Press.

[26] UNCHS (1996). United Nations Conference on Human Settlement, The Indicators Programme: Monitoring Human Settlements for the Global Plan of Action, Paper - United Nations Conference on Human Settlement (Habitat II), 
Istanbul, June 1996.

[27] United Nations World Urban Forum (2004). 13-17 September 2004, Barcelona, Spain. http://ww2.unhabitat.org/wuf/2004/. Accessed August $24^{\text {th }} 2014$.

[28] United Nations WUF III (2006). World Urban Forum. Vancouver, Canada. June 19-23, 2006. http://ww2.unhabitat. org/wuf/2006/wuf_story12.asp. Accessed August $24^{\text {th }} 2014$.

[29] UNCSD (2012). United Nations Conference on Sustainable Development Rio+ 20. 20-22 June 2012 Rio de Janeiro Brazil www.uncsd2012.org. Accessed August $10^{\text {th }} 2014$.

[30] UN- HABITAT (2006/2007). State of The World Cities: The Millennium Development Goals and Urban Sustainability, 30 Years of Shaping The Habitat Agenda. USA: Earthscan www.unhabitat.org. United Nations Human Development Programme.

[31] UNDP (2006). World Urbanization Prospective and Human Development Report New York: United Nation Publication. Department of Economic and Social Affair (Population Division).

[32] UN-HABIATAT (2009). Annual Report 2008. Nairobi: UNON/Publishing. www.unhabitat.org. United Nations Human Development Programme.
[33] UN-HABITAT (2010a). The State of African Cities. Governance, Urban Inequality and Urban Land Markets. Nairobi: UNON/Publishing. www.unhabitat.org. United Nations Human Development Programme.

[34] UN-HABITAT (2010b). Planning Sustainable Cities: Practice and Perspective. Nairobi: UNON/Publishing. www.unhabitat.org United Nations Human Development Programme.

[35] UN-HABITAT (2012/2013). State of The World Cities: Prosperity of Cities. New York: Routledge.www.unhabitat.o rg United Nations Human Development Programme.

[36] UN-HABITAT (2014a). The State of African Cities: Re-imaging Urban Transition. Nairobi: Michael Jones. www.unhabitat.org United Nations Human Development Programme.

[37] United Nations (2014b). World Urbanization Prospects: The 2014 Revision. The United Nations Department of Economic and Social Affairs.

[38] UN-WUF (2004). United Nations World Urban Forum. 13-17 September (2004), Barcelona, Spain.

[39] WCED (1987). World Commission on Environment and Development, Our Common Future (The Brundtland Report), Oxford University Press, Oxford. 